\title{
In the Classroom
}

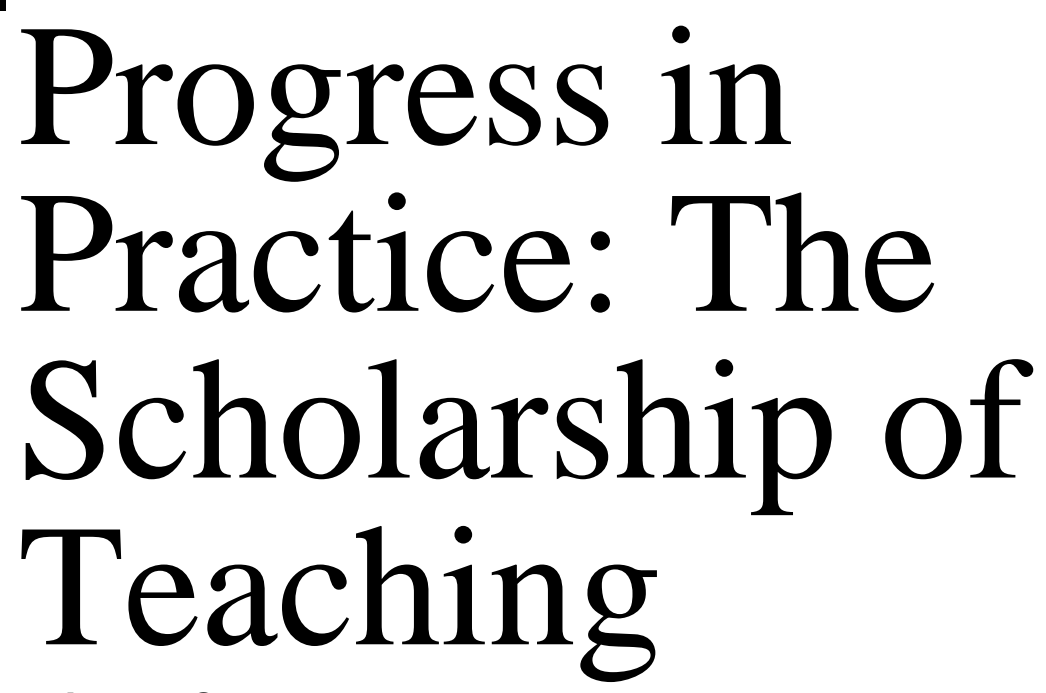

Brian P. Coppola

Department of Chemistry

The University of Michigan

Ann Arbor, MI 48109-1055, USA

bcoppola@umich.edu

\section{As teaching \\ intentions are}

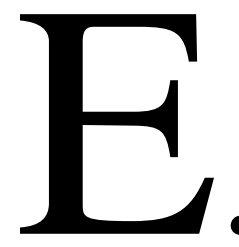

L. Boyer's "Scholarship Reconsidered," published in 1990 [1], is one of the most contemplative answers to the now-familiar reexamination of the - balance between teaching, research, and service recast as specific

goals with

appended within the professoriate. Unlike some imaginative redefinitions of this metaphorical "triple point" problem [2, 3], which advocate more equivalent weightings to the traditional dimensions of professional activity, Boyer recasts scholarly

practices, the

questions about

what is being

assessed are

easier to answer.
*Individuals involved in curriculum design often introduce new, modified, or applied ideas about instruction that span from classroom methods to philosophies of education. In this series, we examine progress in chemical education that is related to actual practices, and where many recommendations have originated from areas in higher education that exist alongside of and overlap with chemistry. Rather than an exhaustive review, we will select examples, background, and vocabulary that may either invite interested newcomers to explore a different area in their teaching, or provide language and precedent for individuals who wish to contextualize ideas they have developed independently.

-Brian P. Coppola, Series Editor 
activity as a comprehensive and integrated view of what faculty do with their time. He posits and elaborates four obligations for faculty:

- the discovery of knowledge

- the integration and synthesis of knowledge

- the application of knowledge

- the representation of knowledge

The American Chemical Society's Division of Chemical Education is among the groups that have proposed criteria for the "scholarship of teaching" based on the tenets outlined by Boyer [4]. The most inclusive and overarching work has been organized by the American Association for Higher Education (AAHE), which established a program in 1990 called "The Teaching Initiative" [5]. Guided by AAHE collaborators such as Shulman [6], Angelo [7, 8], and Barr and Tagg [9], a major focus within the Initiative has been to examine teaching (and learning) from a perspective familiar to faculty: peer collaboration and peer review $[10,11]$.

The AAHE Initiative has brought together faculty who are drawn from diverse disciplines and institutional settings in order for them to explore how the same fundamental ideas about teaching are expressed within the context of specific subject areas. This effort has been a celebration of similarity over difference, where idiosyncrasies that exist for every group are an accepted and natural consequence of each separate disciplinary culture. According to prevailing understanding, teaching and learning are likewise "situated" within the disciplines [12-15]. In other words, "teaching excellence in chemistry" is the application of good teaching principles to the specific (and unique) situation of learning chemistry, also called pedagogical content knowledge [16], which combines a chemist's depth of understanding of the subject matter with an understanding of effective pedagogy. Not surprisingly, two core issues emerging from "the scholarship of teaching" parallel those from the progenitor domain of research. They are "planning and implementation" and "assessment and evaluation".

\section{Planning and Implementation.}

There are many excellent general resources that outline both practical strategies and theoretical underpinnings for instruction [16-21], although there are few that address chemistry instruction broadly [for example: 22] and fewer still that focus on specific 
chemical subdisciplines [for example: 23,24$]$. At any juncture where recommendations about chemistry are involved, we chemists must also be involved: we understand and create chemical knowledge, and we need to be proactively responsible for articulating the expectations from chemistry instruction as well as how they are to be achieved. Indeed, a clear, explicit, and elaborated inventory of instructional goals [25] is perhaps the most ubiquitous recommendation from individuals who study teaching and learning. The more this inventory can extend beyond a list of topics that might appear on a syllabus, or perhaps in a table of contents, the closer we can move from keeping teaching a private and unexamined thing to creating a scholarly and community activity comparable to our other professional work.

Unlike the expectations in our specialized areas of research, where both proposals and results are inextricably tied to methodology, chemistry instructors typically communicate about the content of their courses in terms of subject matter that is not attached to the method of its instruction. Perhaps this is because of a shared, unstated, and unexamined belief that one's level of chemical expertise is the sole arbiter for excellence in instructional ability: "she's a really outstanding chemist so I am sure she gives a good class" and "he really knows his stuff" are familiar expressions of teaching confidence, although rarely the attributes cited by learners (including faculty!) when they reflect on their own experiences with good teachers [16, 19, 26, 27]. Shifting goal-setting means taking a statement such as "teach (or learn) stereochemistry" and evolving it to include the kind of information that allows a scholarly community to examine it. A broad instructional intention, such as "teach stereochemistry," is tranformed into a meaningful goal by putting it into the context of some specific skills and the practices used to encourage their mastery. Should these students be able to examine any structural drawing in any journal article and identify and label stereocenters? Should these students be able to provide a full stereochemical analysis for any molecule with up to 3 stereocenters? What consequences of overall molecular symmetry are significant for learners, expressed in terms of the kinds of problems they should be able to solve? What sorts of classroom work are suited to learning skills associated with stereochemical topics? What sorts of group and individual assignments are effective for which kinds of students? (Assessment and evaluation are tied to instructional goals: How can students best assess their learning prior to examinations? What types of examination questions can best ensure that the desired skills have been learned and also discriminate against less desirable ones?) 
We have recommended that there are categories of goals that are useful to address separately [28, 29]: How does learning chemistry address the general intellectual objectives for a liberal arts education? Only chemists can answer this question, but not without first participating in a broader conversation about the goals of a liberal education [30]. Professional intellectual objectives are the overarching values for a more specific literacy at the disciplinary level. The fundamental questions that chemistry asks of the world, for example, would be comprehensively representative of the discipline. These are the strands that could explicitly link formal courses and a student's experience within them during a chemistry curriculum. Instruction would also need to attend to the connection between the professional and general intellectual objectives. Lastly, individual courses are embedded within the richness of professional technical objectives: the skills and factual subject matter surrounding topics such as stereochemistry. Technological progress in chemistry and the detailed articulation of the professional technical subject matter should be exploited in order to make clear connections about how learning stereochemistry is not only representative of professional intellectual objectives, but also addresses general intellectual ones. To reiterate: only we chemists can provide these connections because we are the ones who understand chemistry best; but our understanding is the beginning of the conversation, not the end of it.

\section{Assessment and Evaluation}

An integrated view of assessment practices is emerging [7, 16, 17, 19, 20, 25]. Whether from student examinations or educational and psychological research experiments, feedback from students is being used to help understand and inform the teaching process. As teaching intentions are recast as specific goals with appended practices, the questions about what is being assessed are easier to answer. The match between goals and practices, and also assessment methods, however, is a reasonable expectation that has not been explicitly realized in a way that can be easily examined. A great deal of work is needed before this can happen, from a consensus about basic language to what constitutes general literacy in the area of chemical education.

The AAHE Teaching Initiative has added the dimensions of peer collaboration and peer review to the menu of choices for assessment. It has also promoted the useful distinction between an evaluation that is used to inform and improve instruction by feeding back outcomes in order to modify planning and implementation (formative evaluation), and an 
evaluation that is used to make judgments about teaching effectiveness for either programs or individuals (summative evaluation). As is true with traditional notions of scholarship, normative expectations for faculty performance are critical for actually carrying out evaluations, not only for refereeing an individual's contributions, but also for guiding the practice of novices. These standards can only be determined through experience, which suggests that a generation of patience is needed while the scholarship of teaching is developed and implemented. Evaluations also play an equally significant role in promoting improvement in the effectiveness of a system or in helping individuals to realize their potentials.

The handbook developed by Angelo and Cross [25] is a rich resource for assessment techniques that can, in turn, be used for formative improvements in the classroom. Most of the assessment strategies represent excellent pedagogical strategies that, if implemented, serve to provide focused feedback from students to their instructors. For example, soliciting written, anonymous feedback to questions such as "What was the most important thing you learned today?" and "What question remains uppermost in your mind?" were the basis for the "One-Minute Paper" [7, 25, 31]. An instructor can scan and use these papers to help understand actual (rather than imagined) learning. This simple and easily implemented idea can be adapted in many ways, including having students generate examples that can be used as the basis for immediate classroom discussion between groups of students, between the instructor and the class, or for a problem set that is returned or posted for the class to analyze (Create 5 examples of acylation reactions that result in different functional groups as products) [24]. As we have stated previously [28], there is more than a metaphorical relationship between effective instruction and the questions asked by anyone trying to communicate: the speakers in a conversation, who are the teachers, want to know: "Am I being understood?" and "How do I know?" Listeners, who are the learners, assess their own understanding with an analogous set of questions.

The menu of assessment strategies that the AAHE has developed [11] for faculty who wish to explore peer collaboration and peer review includes:

- Reciprocal visits and observation

- Mentoring of inexperienced instructors

- Using classroom assessment to improve instruction

- Course portfolios [32, 33] 
- Team teaching and cross-disciplinary conversations

- Creating opportunities for intradepartmental collaborations

- Interdepartmental collaborative classroom research

- Intercampus collaborations and external peer review

The "scholarship of teaching" originally outlined by Boyer [1] has set the stage for many creative attempts to involve faculty in their teaching obligations in the way that faculty involve themselves in their disciplinary specialties. It seeks to move faculty to the center of instructional practice, where improvement is progress and something that is done "by them" and not "to them." The scholarship effort also seeks to change faculty beliefs about teaching and learning in compelling and familiar ways, away from a set of techniques ("tricks") tied to an instructor's or a student's personality and towards a set of intellectually engaging problems that represent authentic learning experiences for everyone involved. Finally, it recognizes that any changes to the value system within the academy will also come from within: broadening notions of scholarship in ways that are created and driven by the faculty will ultimately become a part of the comprehensive definition of what it means to be a member of the professoriate.

\section{ACKNOWLEDGMENT}

The author thanks The University of Michigan Center for Research on Learning and Teaching for their local support of the AAHE Peer Review Project, and also for a Faculty Associate position during 1995-96.

\section{REFERENCES}

1. Boyer, E. L. Scholarship Reconsidered: Priorities of the Professoriate; Carnegie Foundation for the Advancement of Teaching: Princeton, N. J, 1990.

2. Gilmer, P. J.; Engel, S. Abstracts of Papers, 69th Meeting of National Association for Research in Science Teaching, St. Louis, MO, 1996, p 116.

3. Essay by Gilmer, P. J. Available URL at http://tinker.housing.fsu.edu/ jhebert/hec/pennygilmer .html.

4. Herron, D. "Chemical Education Research: Task Force Report" Division of Chemical Education (CHED) Newsletter, Fall, 1996, 23. 
5. AAHE Teaching Initiative (P. Hutchings, program director; P. Bender, program coordinator) American Association for Higher Education, One Dupont Circle, Suite 360, Washington, D.C. Available URL for AAHE at http://www.ido.gmu.edu/aahe/welcome.html.

6. Shulman, L. S. "Teaching as Community Property” Change 1993, 25(6), 6.

7. Angelo, T. A. "Introduction and Overview: From Classroom Assessment to Classroom Research." In Angelo, T. A. Ed.; Classroom Research: Early Lessons from Success. New Directions for Teaching and Learning No. 46; Jossey-Bass: San Francisco, 1991, pp 7-15.

8. Angelo, T. A. "Ten Easy Pieces: Assessing Higher Learning in Four Dimensions" In Angelo, T. A. Ed.; Classroom Research: Early Lessons from Success. New Directions for Teaching and Learning, No. 46; Jossey-Bass: San Francisco, 1991, pp17-31.

9. Barr, R. B.; Tagg, J. "From Teaching to Learning. A New Paradigm for Undergraduate Education" Change 1995, 27(6), 13.

10. From Idea to Prototype: The Peer Review of Teaching: A Project Workbook; Hutchings, P., Ed.; American Association of Higher Education: Washington, D.C., 1995.

11. Hutchings, P. Making Teaching Community Property: A Menu for Peer Collaboration and Peer Review; American Association of Higher Education: Washington, D.C., 1996.

12. Shulman, L. S. "Those Who Understand: Knowledge Growth in Teaching." Educational Researcher 1986, 15(2), 4.

13. Ennis, R. H. "Critical Thinking and Subject Specificity: Clarification and Needed Research" Educational Researcher 1989, 18(8), 4.

14. McPeck, J. E. "Critical Thinking and Subject Specificity: A Reply to Ennis" Educational Researcher 1990, 19(4), 10.

15. Ennis, R. E. "The Extent to Which Critical Thinking is Subject-Specific: Further Clarification" Educational Researcher 1990, 19(4), 13.

16. McKeachie, W. J. Teaching Tips: Strategies, Research, and Theory for College and University Teachers, 9th ed.; D. C. Heath: Lexington, MA, 1994.

17. Handbook of College Teaching: Theory and Applications; Prichard, K. W.; Sawyer, R. M., Eds.; Greenwood: Westport, CT, 1994.

18. Lambert, L. M.; Tice, S. L.; Featherstone, P. H. University Teaching: A Guide for Graduate Students; Syracuse University Press: Syracuse, N.Y., 1996. 
19. Lowman, J. Mastering the Techniques of Teaching, 2nd ed.; Jossey-Bass: San Francisco, 1995.

20. Teaching on Solid Ground: Using Scholarship to Improve Practice. Menges, R. J.; Weimer, M., Eds.; Jossey-Bass: San Francisco, 1996.

21. Hutchings, P. Using Cases to Improve College Teaching: A Guide to More Reflective Practice; American Association of Higher Education: Washington, D.C., 1993.

22. Orna, M. V. "Chemistry Education: Context, Theory, and Practice." In, reference 17, pp. 217228.

23. van Keulen, H. Making Sense: Simulation-of-Research in Organic Chemistry Education CD- $\beta$ Press: Utrecht, The Netherlands, 1995.

24. Coppola, B. P. "Progress in Practice: Using Concepts from Motivational and Self-regulated Learning Research to Improve Chemistry Instruction. Understanding Self-Regulated Learning" Pintrich, P. R., Ed.; New Directions for Learning and Teaching, No. 63; Jossey-Bass: San Francisco, 1995, pp 87-96.

25. Angelo, T. A.; Cross, K. P. Classroom Assessment Techniques: A Handbook for College Teachers, 2nd ed.; Jossey-Bass: San Francisco, 1993.

26. Weimer, M. Improving Your Classroom Teaching; SAGE Publications: Newbury Park, CA:, 1993.

27. Coppola, B. P.; Pearson, W. H. "Heretical Thoughts II: These on Lessons We Learned from Our Graduate Advisor That Have Impacted on Our Undergraduate Teaching" Journal of College Science Teaching, submitted.

28. Coppola, B. P.; Daniels, D. S. "Structuring the Liberal (Arts) Education in Chemistry", Chem. Educator 1996, 1(2): S 1430-4171(96)02018-3. Avail. URL: http://journals.springerny.com/chedr

29. Coppola, B. P.; Daniels, D. S. "Mea Culpa: Formal Education and the Dis-Integrated World" Science and Education, in press.

30. Ege, S. N.; Coppola, B. P. ; Lawton, R. G. "The New Undergraduate Chemistry Curriculum at the University of Michigan. 1. Philosophy, Curriculum, and the Nature of Change" J. Chem. Educ., in press.

31. Wilson, R. C. "Improving Faculty Teaching: Effective Use of Student Evaluations and Consultants." Journal of Higher Education 1986, 57, 196. 
32. Edgerton, R.; Hutchings, P.; Quinlan, K. The Teaching Portfolio: Capturing the Scholarship of Teaching; American Association of Higher Education: Washington, D.C., 1991.

33. Campus Use of the Teaching Portfolio: Twenty-Five Profiles; Anderson, E., Ed.; American Association of Higher Education: Washington, D.C., 1993. 